DOI https://doi.org/10.30525/978-9934-26-111-4-22

\title{
DEPENDENCE OF BIOELECTRICITY PRODUCTION FROM ELECTROTECHNOLOGICAL PARAMETERS OF PLANT-MICROBIAL ELECTRO-BIOSYSTEMS
}

\author{
Rusyn I. B. \\ Candidate of Biological Sciences, Associate Professor, \\ Doctoral Student at the Department of Ecology and Sustainable \\ Environmental Management \\ Viacheslav Chornovil Institute of Sustainable Development \\ Lviv Polytechnic National University \\ Djachok V. V. \\ Doctor of Technical Sciences, \\ Professor at the Department of Ecology and Sustainable Environmental \\ Management, \\ Viacheslav Chornovil Institute of Sustainable Development \\ Lviv Polytechnic National University \\ Lviv, Ukraine
}

The principle of operation of plant-microbial electro-biosystems is based on the collection of bioelectric energy generated by electro-active microorganisms localized in the rhizosphere of plants using electrodes [1,2]. Plants form photosynthetants in excess and some of these products not required for metabolism are excreted by the root system in the substrate [35]. Organic root excretants and carbon dioxide, as well as plant precipitation and the substrate compounds themselves serve as sources of nutrition for rhizosphere microorganisms [6,7]. Microbial conversion is accompanied by the donation of electrons to the electrodes and the generation of bioelectricity $[1,3,8]$.

Plant-microbial electro-biosystem can be considered as a hybrid bioelectrochemical device, because both electrotechnological and biological components, such as electrode material, their interelectrode distance and location, load, type and stage of plant development are important for the functioning of electro-biosystems [ 5, 9-11]. In electro-biosystems based only on microorganisms, it has been shown that reducing the distance between the electrodes in the electro-biosystem can increase its power [9, 12-14]. By changing the species of plants in the same electro-biosystems based on the same anodes and cathodes, their different efficiency was 
demonstrated [15-17]. Taking into account the importance and little-studied role of interelectrode distance in the functioning of plant-microbial electrobiosystems, we set ourselves the task to investigate the influence of the distance between the anode and cathode on the bioelectric potential and current of electro-biosystems from Lemna minor in the laboratory conditions.

To conduct the research, electro-biosystems with $L$. minor plants obtained from contaminated ditches, natural substrate and electrodes [18], which were placed in the substrate around the duckweed roots at different distances from 1 to $10 \mathrm{~cm}$ were constructed.

The growth of bioelectric parameters with a decrease in the interelectrode distance was demonstrated both when using short-term connected resistors of $500 \mathrm{Ohms}, 1 \mathrm{kOhm}$, and without the use of load. Electro-biosystems of plate configuration with an interelectrode distance of $1 \mathrm{~cm}$ were characterized by $0.203 \mathrm{~V}$ higher values of bioelectric potential than electro-biosystems with a $10 \mathrm{~cm}$ interelectrode distance with a shortterm connection of a $500 \mathrm{Ohm}$ resistor (Fig. 1).

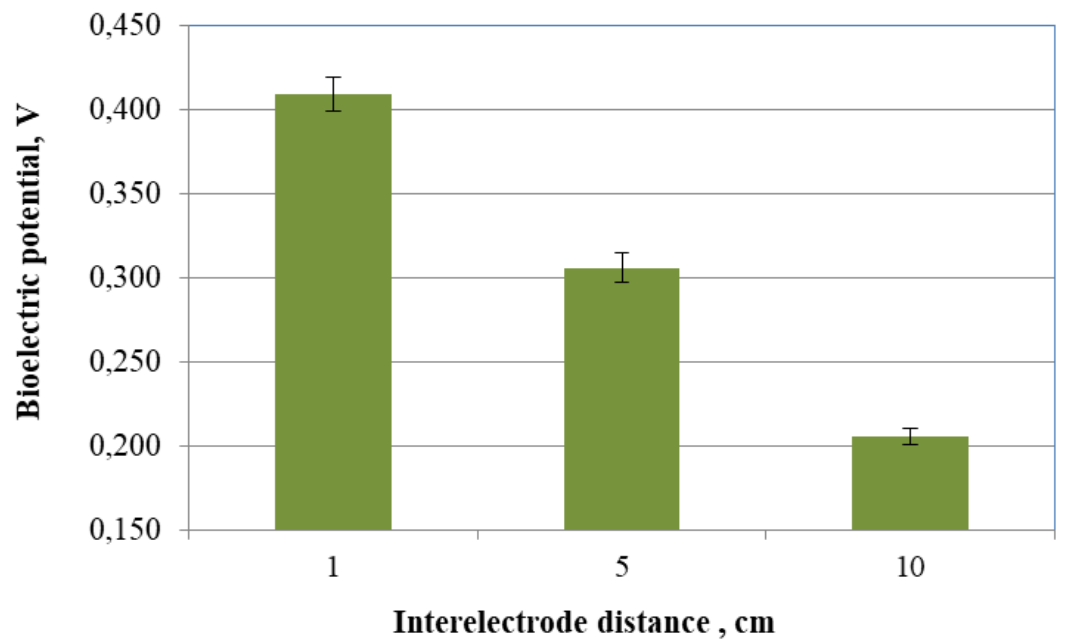

Fig. 1 Influence of interelectrode distance on bioelectric potential of electro-biosystem with $L$. minor at short-term loading of $500 \mathrm{Ohm}$ $(x \pm S E, n=7)$ 
Similar trends were observed with short-term connection of $1 \mathrm{kOhm}$ resistors and without load. Obviously, reducing the distance between the electrodes reduces the internal resistance, leads to faster electron and proton transfer to the electrodes and prevents the influence of competing microorganisms of electrons and protons. The identified effect has important value for modeling efficient plant-microbial electro-biosystems.

\section{References:}

1. Strik D.P.B.T.B., Hamelers H.V.M., Snel J.F.H., Buisman C.J. Green electricity production with living plants and bacteria in a fuel cell. International Journal of Energy Research. 2008. Vol. 32, № 9. 870-876. DOI: 10.1002/er.1397

2. Kaku N., Yonezawa N., Kodama Y., Watanabe K. Plant/microbe cooperation for electricity generation in a rice paddy field. Applied Microbiology and Biotechnology. 2008. Vol. 79, № 1. P. 43-49. doi: 10.1007/s00253-008-1410-9

3. Lynch J.M, Whipps J.M. Substrate flow in the rhizosphere. Plant and Soil. 1990. Vol. 129, № 1. P. 1-10.

4. Helder M., Chen W.S., Van Der Harst E.J.M., Strik D.P.B.T.B., Hamelers H.V.M., Buisman C.J.N., Potting J. Electricity production with living plants on a green roof: environmental performance of the plantmicrobial fuel cell. Biofuels, Bioproducts and Biorefining. 2013. Vol. 7. P. 52-64. DOI: 10.1002/bbb.1373

5. Nitisoravut R., Regmi R. Plant microbial fuel cells :A promising biosystems engineering. Renewable and Sustainable Energy Reviews. 2017. Vol. 76. P. 81-89. DOI: 10.1016/j.rser.2017.03.064

6. Deng H., Chen Z., Zhao F. Energy from Plants and Microorganisms: Progress in Plant-Microbial Fuel Cells. ChemSusChem. 2012. Vol. 5. P. 1006-1011. DOI: 10.1002/cssc.201100257

7. Timmers R.A., Rothballer M., Strik D.P.B.T.B., Engel M., Schulz S., Schloter, M., Hartmann A., Hamelers B., Buisman C. Microbial community structure elucidates performance of Glyceria maxima plant microbial fuel cell. Applied Microbiology and Biotechnology. 2012. Vol. 94, № 2. P. 537-548. DOI: 10.1007/s00253-012-3894-6

8. De Schamphelaire L., Van Den Bossche L., Hai, S.D., Höfte M., Boon N., Rabaey K., Verstraete W. Microbial fuel cells generating electricity from rhizodeposits of rice plants. Environmental Science and Technology. 2008. Vol. 42, № 8. P. 3053-3058. DOI: 10.1021/es071938w

9. Sangeetha T., Muthukumar M. Influence of electrode material and electrode distance on bioelectricity production from sago-processing 
wastewater using microbial fuel cell. Environmental Progress and Sustainable Energy. 2013. Vol. 32, № 2. P. 390-395. DOI: 10.1002/ep.11603

10. Kalathil S., Patil S.A., Pant D. Microbial Fuel Cells: Electrode materials / K. Wandelt, P. Vadgama . Encyclopedia of Interfacial Chemistry: Surface science and Electrochemistry. Amsterdam: Elsevier, 2017. 5560 p. DOI: 10.1016/B978-0-12-409547-2.13459-6

11. Kabutey F.T., Zhao Q., Wei L., Ding J., Antwi P., Quashie F.K., Wang W. An overview of plant microbial fuel cells (PMFCs): Configurations and applications. Renewable and Sustainable Energy Reviews. 2019. Vol. 110 (C). P. 402-414. DOI: 10.1016/j.rser.2019.05.016

12. Cheng S., Liu H., Logan B.E. Increased power generation in a continuous flow MFC with advective flow through the porous anode and reduced electrode spacing. Environmental Science and Technology. 2006. Vol. 40. P. 2426-2432. DOI: 10.1021/es051652w

13. Jang J.K., Pham T.H., Chang I.S., Kang K.H., Moon H., Cho K.S., Kim B.H. Construction and operation of a novel mediator- and membraneless microbial fuel cell. Process Biochemistry. 2004. Vol. 39. P. 1007-1012.

14. Hadagali A., Shalini R., Pratima B. Comparative studies on electrodes for the construction of microbial fuel cell. International Journal of Advanced Biotechnology and Research. 2012. Vol. 3, № 4. P. 785-789.

15. Helder M., Strik D.P.B.T.B., Hamelers H.V.M., Kuhn A.J., Blok C., Buisman C.J.N. Concurrent bio-electricity and biomass production in three Plant-Microbial Fuel Cells using Spartina anglica, Arundinella anomala and Arundo donax. Bioresource Technology. 2010. Vol. 101, № 10. P. 3541-3547. DOI: 10.1016/j.biortech.2009.12.124

16. Wang J., Song X., Wang Y., Bai J., Li M., Dong G., Lin F., Lv Y., Yan D. Bioenergy generation and rhizodegradation as affected by microbial community distribution in a coupled constructed wetland-microbial fuel cell system associated with three macrophytes. Science of the Total Environment. 2017. Vol. 607-608. P. 53-62. DOI: 10.1016/j.scitotenv.2017.06.243

17. Oodally A., Gulamhussein M., Randall D.G. Investigating the performance of constructed wetland microbial fuel cells using three indigenous South African wetland plants. Journal of Water Process Engineering. 2019. Vol. 32, № 100930. P. 1-8. DOI: 10.1016/j.jwpe.2019.100930

18. Русин І.Б., Медведєв О.В. Спосіб отримання біологічної електрики 3 глибинних шарів грунту: пат. 112093 Україна: МПК 2016.01, Н05F 7/00, Н01М 8/16; заявл. 9.03.2016; опубл. 12.12.2016. Бюл. № 23.5 c. 